Part of Journal of Research of the National Bureau of Standards, Volume 19, November 1937

\title{
STUDY OF BALL PACKINGS FOR LABORATORY RECTIFYING COLUMNS ${ }^{2}{ }^{2}$
}

\author{
By Augustus R. Glasgow, Jr., ${ }^{3}$ and Sylvester T. Schicktanz ${ }^{4}$
}

\section{ABSTRACT}

The efficiency, liquid hold-up, and surface area of packings composed of glass balls 2.95 and $3.80 \mathrm{~mm}$ in diameter, lead balls 2.05 and $4.05 \mathrm{~mm}$ in diameter, and copper balls $4.00 \mathrm{~mm}$ in diameter, have been determined. The description and operation of the glass experimental column are given. For a column $2.6 \mathrm{~cm}$ in diameter packed with balls 0.2 to $0.4 \mathrm{~cm}$ in diameter, it is found that: (1) the heat conductivity and the nature of the material of the packing bave no effect on the efficiency of separation, liquid hold-up, or through-put of the still; (2) the efficiency is substantially directly proportional to the total surface area exposed in the packed column, and approximately linear with the reciprocal of the diameter of the balls; and (3) the hold-up is approximately linear with the total surface area.

\section{CONTENTS}

I. Introduction

II. Description of distillation assembly

III. Packings investigated . .

IV. "Test" mixture used

V. Experimental procedure and data.

1. Determination of optimum back pressure

2. Determination of efficiency of separation

3. Determination of hold-up

4. Determination of vapor velocity

5. Determination of surface area of packing

VI. Discussion of results

\section{INTRODUCTION}

The purpose of the present investigation was to obtain information concerning the effect of the following factors on the efficiency, hold-up, and related properties of laboratory distilling columns: (1) the nature of the material of the packing; (2) the surface area of the packing; and (3) the size of the packing. The nature of the material was varied by using balls of approximately the same diameter $(4 \mathrm{~mm})$ made of materials of quite different heat conductivities. The total surface and the size of the packing were varied by using balls of different diameters (2 to $4 \mathrm{~mm}$ ).

1 Financial assistance for this work has been received from the research fund of the American Petroleum Institute. This work is part of Project 6, The Separation, Identification, and Determination of the Con-

stituents of Petroleum. the University of Maryland in partial fulfillment of the requirements for the degree of Master of Science.

3 Research Associate at the National Bureau of Standards, representing the American Petroleum Institute.

- Formerly associated with A PI Research Project 6, now with Alcohol Tax Unit, Bureau of Internal

Revenue, U. S. Treasury Department. 


\section{DESCRIPTION OF DISTILLATION ASSEMBLY}

In figure 1 is shown, to scale, the complete distillation unit used to determine the various characteristics of the different packings investigated. The apparatus is made of Pyrex glass throughout and sealed together to insure against leaks during operation.

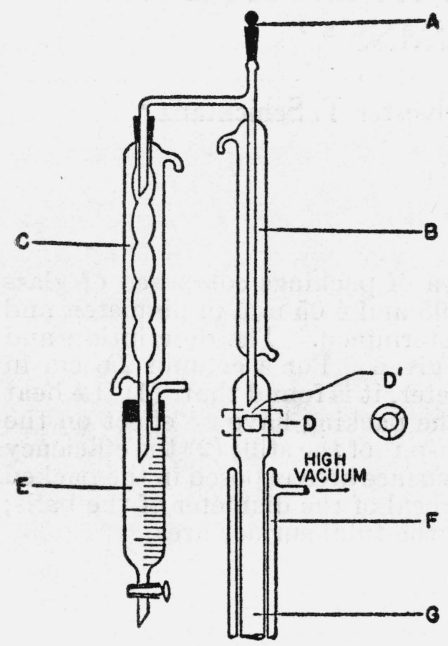

The assembly consists of a 1-liter still pot $N$, equipped with a tube $K$ for convenience in introducing and removing the test mixture, and a capillary tube $M$, whose upper end empties into the vial $I$ for removing small test samples during operation. The column proper, $G$, is $25.8 \mathrm{~mm}$ in internal diameter and $140 \mathrm{~cm}$ long, and contains a sealed-in cross bar, $L, L^{\prime}$, to support the packing. In the upper part is sealed a small cup, $D, D^{\prime}$, of $2-\mathrm{ml}$ capacity, which collects the condensate returning from the condenser $B$. $A$ is a ground-glass stopper, through which samples are removed from the cup $D^{\prime}$ by means of a long capillary pipette. $C$ is an auxiliary condenser used during actual distillation, and $E$ is a receiver unit for collecting the distillate.

To maintain a constant back pressure, and consequently a constant rate of boiling, the still pot is connected to the manometer $J$, which automatically controls the energy input to the heating unit $O$, by means of a set of electrical relays and resistances not shown in the figure. Variations in the rate of distillation are obtained by adjustment of the screw $H$ attached to the contact point in the manometer.

To maintain adiabatic conditions during the tests, the column is surrounded by a vacuum-jacketed sleeve $F$, which is completely silvered except for narrow, clear vertical windows $1 \mathrm{~cm}$ wide in both front and back, which permit visual inspection of the column during operation. To obtain and maintain a constant low pressure $\left(10^{-5} \mathrm{~mm}\right.$ $\mathrm{Hg}$ ), the jacket is connected to a mercury diffusion pump, which is operated continuously.

\section{PACKINGS INVESTIGATED}

Figure 1.-Assembly of all-glass rectifying still in which the various packings were investigated.

The ball type of packing was selected for investigation for the following reasons: the surface area can be readily determined; the 
area of contact between units is small; the distribution is fairly uniform; and the volume of free space does not change markedly with the size of the balls.

Two sizes of soft-glass balls were used, the average diameters being 3.80 and $2.95 \mathrm{~mm}$, respectively, with an average deviation of approximately 10 percent. The copper packing consisted of machined balls having an average diameter of $4.00 \mathrm{~mm}$, with a variation of about 1 percent. The lead balls were of two sizes, having average diameters of 4.05 and $2.05 \mathrm{~mm}$, respectively, with a variation of about 10 percent in each case. The lead balls were not perfect spheres and, because of the softness of the material, tended to be flattened at the points of contact.

The locket-chain packing was made of brass and had single links. The wire from which the links were made had an average diameter of $0.33 \mathrm{~mm}$ and each link had a circumference of $6.2 \mathrm{~mm}$.

\section{IV. “TEST" MIXTURE USED}

In order to calculate the number of theoretical plates in a distillation column, it is necessary to use, as a "test" mixture, a binary system whose vapor-liquid phase diagram is known. The binary system of benzene and ethylene chloride $[1]^{5}$ was chosen for the following reasons: the mixture is nearly an ideal one; the difference in boiling point $\left(3.5^{\circ} \mathrm{C}\right)$ of the two constitutents is small; the vapor-liquid phase diagram is known [2]; and the determination of the composition can be made readily by means of measurements of refractive index. The constants for the two components used in the mixture are: benzene, bp (760 mm) $80.2^{\circ} \mathrm{C}, n_{D}^{25.2} 1.4976$; ethylene chloride, bp (760 mm) $83.7^{\circ} \mathrm{C}, n_{D}^{25.2} 1.4418$. The number of theoretical plates was determined with this binary mixture by means of the graphical method of McCabe and Thiele [3].

\section{EXPERIMENTAL PROCEDURE AND DATA}

\section{DETERMINATION OF OPTIMUM BACK PRESSURE}

The resistance to the flow of vapor ascending from the still pot to the still head produces a back pressure. The optimum back pressure is that which yields the greatest separation of the two components when the column is operating with a high vapor velocity. A discussion of the variation of the number of theoretical plates with vapor-velocity is given in an article by Arthur Rose [4].

An $800-\mathrm{ml}$ sample of the test mixture of known composition (approximately 40 mole percent of benzene and 60 mole percent of ethylene chloride) was charged into the still and sufficient material (about $50 \mathrm{ml}$ ) was distilled to remove a small amount of water that adhered to the packing and to the walls of the column. The back pressure was then set at some arbitrary value and the still run under total reflux. Samples of the liquid distillate and of the liquid in the pot were withdrawn and their composition determined. Consecutive check determinations, taken 10 minutes apart, served to indicate when the column was in equilibrium. The pressure was then varied several millimeters by changing the energy input at the pot, and the measure-

${ }_{5}$ The figures given in brackets here and elsewhere in the text correspond to the numbered references at the end of the paper. 
ments were repeated. In this manner it was possible to determine the back pressure that produced the greatest separation. Table 1 shows the variation of back pressure with the various packings.

TABLE 1.-Data obtained on measurements of back pressure

\begin{tabular}{|c|c|c|c|c|}
\hline \multirow{2}{*}{ Type of packing } & \multirow{2}{*}{$\begin{array}{c}\text { Observa- } \\
\text { tion }\end{array}$} & \multirow{2}{*}{$\begin{array}{l}\text { Back pres- } \\
\text { sure }\end{array}$} & \multicolumn{2}{|c|}{ Mole percent of benzene } \\
\hline & & & Vapor & Pot \\
\hline $\begin{array}{l}\text { Glass balls }(3.80 \mathrm{~mm} \text { diam) } \\
\text { Copper balls }(4.00 \mathrm{~mm} \text { diam) } \\
\text { Glass balls }(2.95 \mathrm{~mm} \text { diam) } \\
\text { Lead balls }(2.05 \mathrm{~mm} \text { diam) } \\
\text { Locket chain }(0.33 \mathrm{~mm} \text { diam of rod and } 6.2 \mathrm{~mm} \text { circum } \\
\text { ference of link })\end{array}$ & $\begin{array}{l}1 \\
2 \\
3 \\
1 \\
2 \\
3 \\
1 \\
2 \\
3 \\
1 \\
2 \\
3 \\
1 \\
2 \\
3 \\
4\end{array}$ & $\begin{array}{r}\mathrm{mm} \\
5 \\
10 \\
15 \\
8 \\
10 \\
12 \\
14 \\
12 \\
10 \\
17 \\
15 \\
13 \\
15 \\
12 \\
10 \\
8\end{array}$ & $\begin{array}{l}74.8 \\
75.2 \\
74.0 \\
58.3 \\
59.0 \\
58.0 \\
78.0 \\
80.7 \\
79.8 \\
80.3 \\
81.0 \\
80.7 \\
79.2 \\
84.5 \\
85.0 \\
85.0\end{array}$ & $\begin{array}{r}37.2 \\
-37.2 \\
37.0 \\
20.0 \\
220.0 \\
20.0 \\
37.0 \\
-37.0 \\
37.0 \\
26.2 \\
-20.6 \\
21.4 \\
34.6 \\
34.3 \\
\bullet 34.0 \\
34.0\end{array}$ \\
\hline
\end{tabular}

- Value used for the determination of the number of theoretical plates.

The optimum back pressure for the locket chain and for the balls of approximately $4 \mathrm{~mm}$ diameter was found to be about $10 \mathrm{~mm}$ of mercury. With the smaller balls of 3 and $2 \mathrm{~mm}$ diameter, the optimum back pressures were, respectively, 12 and $15 \mathrm{~mm}$. This increase in pressure drop for the smaller balls was caused by the greater resistance offered to the flow of vapor by the smaller interstices formed in packing, since the free space remained substantially constant.

\section{DETERMINATION OF EFFICIENCY OF SEPARATION}

The number of theoretical plates was evaluated by the graphical method [3], the composition of vapor and liquid being obtained with the still operating at the optimum back pressure. The composition of the binary mixture of benzene and ethylene chloride was varied to correspond with different regions of the phase diagram by distilling some of the material and then changing again to total reflux. The value of $(n-1)$ theoretical plates, ${ }^{6}$ divided by the height of the packing in the column gives the height equivalent to one theoretical plate (hetp).

TABLE 2.-Data on the efficiency of separation obtained with various packings

\begin{tabular}{|c|c|c|c|c|c|}
\hline \multirow{2}{*}{$\begin{array}{l}\text { Determina- } \\
\text { tion }\end{array}$} & \multicolumn{2}{|c|}{$\underset{n_{D^{25.2}}}{\text { Refractive index }}$} & \multicolumn{2}{|c|}{$\begin{array}{l}\text { Mole percent of } \\
\text { benzene }\end{array}$} & \multirow{2}{*}{$\begin{array}{c}\text { Number of } \\
\text { theoretical } \\
\text { plates less one } \\
n-1\end{array}$} \\
\hline & Vapor & Pot & Vapor & Pot & \\
\hline
\end{tabular}

GLASS BALLS (3.8 $\mathrm{mm}$ diameter)

\begin{tabular}{|c|c|c|c|c|c|}
\hline 3. & $\begin{array}{l}1.4832 \\
1.4807 \\
1.4784 \\
1.4753\end{array}$ & $\begin{array}{l}1.4614 \\
1.4575 \\
1.4555 \\
1.4522\end{array}$ & $\begin{array}{l}75.3 \\
71.2 \\
67.0 \\
61.6\end{array}$ & $\begin{array}{l}36.6 \\
29.4 \\
25.8 \\
19.5\end{array}$ & $\begin{array}{r}22 \\
21 \\
21 \\
22 \\
\text { A verage } . . .21 .5\end{array}$ \\
\hline
\end{tabular}

- The number of theoretical plates was determined to the neareast one-half plate.

o $n$ is the total number of theoretical plates that the entire still produces. $(n-1)$ is the number attributed to the column proper. One plate is subtracted for the change from the pot to the column. 
TABLE 2.-Data on the efficiency of separation obtained with various packings-Con.

\begin{tabular}{|c|c|c|c|c|c|}
\hline \multirow{2}{*}{$\begin{array}{l}\text { Determina- } \\
\text { tion }\end{array}$} & \multicolumn{2}{|c|}{$\begin{array}{l}\text { Refractive index } \\
n_{D^{25.2}}\end{array}$} & \multicolumn{2}{|c|}{$\begin{array}{l}\text { Mole percent of } \\
\text { benzene }\end{array}$} & \multirow{2}{*}{$\begin{array}{c}\text { Number of } \\
\text { theoretical } \\
\text { plates less one } \\
n-1\end{array}$} \\
\hline & Vapor & Pot & Vapor & Pot & \\
\hline
\end{tabular}

GLASS BALLS, PLUS COPPER BALLS (50:50 mixture; glass, $3.8 \mathrm{~mm}$ diameter; copper, $4.0 \mathrm{~mm}$ diameter)

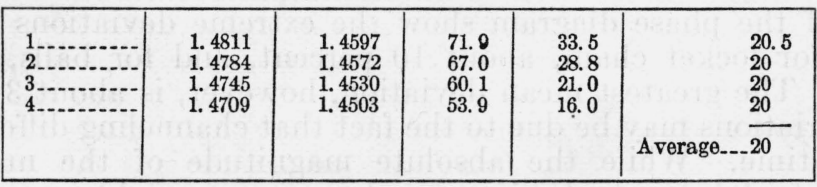

COPPER BALLS (4.0 mm diameter; length of packing $5 \mathrm{~cm}$;less)

\begin{tabular}{|c|c|c|c|c|c|}
\hline $\begin{array}{l}1 \\
2 \\
3 \\
4 \\
4\end{array}$ & $\begin{array}{l}1.4812 \\
1.4797 \\
1.4772 \\
1.4738\end{array}$ & $\begin{array}{l}1.4610 \\
1.4587 \\
1.4556 \\
1.4526\end{array}$ & $\begin{array}{l}72.0 \\
69.4 \\
65.0 \\
59.0\end{array}$ & $\begin{array}{l}36.0 \\
31.6 \\
26.0 \\
20.2\end{array}$ & $\begin{aligned} & 19 \\
& 19.5 \\
& 19 \\
& 20 \\
& \text { Average_...19.5 }\end{aligned}$ \\
\hline
\end{tabular}

LEAD BALLS (4.05 mm diameter)

\begin{tabular}{|c|c|c|c|c|c|}
\hline $\begin{array}{l}1 \\
2 \\
3 \\
4\end{array}$ & $\begin{array}{l}1.4808 \\
1.4780 \\
1.4753 \\
1.4714\end{array}$ & $\begin{array}{l}1.4595 \\
1.4554 \\
1.4528 \\
1.4518\end{array}$ & $\begin{array}{l}71.3 \\
66.3 \\
61.6 \\
54.8\end{array}$ & $\begin{array}{l}33.7 \\
25.6 \\
20.6 \\
18.8\end{array}$ & \begin{tabular}{r}
20 \\
20 \\
20 \\
19 \\
\cline { 2 - 2 } \\
Average $\ldots . .20$
\end{tabular} \\
\hline
\end{tabular}

GLASS BALLS (2.95 $\mathrm{mm}$ diameter)

\begin{tabular}{|c|c|c|c|c|c|}
\hline $\begin{array}{l}1 \\
2 \\
3 \\
4\end{array}$ & $\begin{array}{l}\text { 1. } 4862 \\
1.4829 \\
1.4784 \\
1.4709\end{array}$ & $\begin{array}{l}1.4599 \\
1.4548 \\
1.4500 \\
1.4456\end{array}$ & $\begin{array}{l}80.5 \\
74.8 \\
67.0 \\
53.8\end{array}$ & $\begin{array}{r}33.8 \\
24.3 \\
15.2 \\
7.2\end{array}$ & $\begin{array}{r}28 \\
28 \\
28 \\
28 \\
\text { A verage }-.-28\end{array}$ \\
\hline
\end{tabular}

LEAD BALLS (2.05 $\mathrm{mm}$ diameter)

\begin{tabular}{|l|l|l|l|l|l|}
\hline $1 . \ldots \ldots \ldots$ & 1.4893 & 1.4572 & 85.8 & 28.8 & 36 \\
$2 . \ldots \ldots$ & 1.4883 & 1.4549 & 84.1 & 24.6 & 37 \\
& 1.4865 & 1.4523 & 81.0 & 19.6 & 37 \\
\hline
\end{tabular}

LOCKET CHAIN ( $0.33 \mathrm{~mm}$ diameter of rod; link $6.2 \mathrm{~mm}$ in circumference)

\begin{tabular}{|c|c|c|c|c|c|}
\hline $\begin{array}{l}1 \\
2 \\
3 \\
4 \\
5 \\
6 \\
7\end{array}$ & $\begin{array}{l}1.4888 \\
1.4876 \\
1.4872 \\
1.4858 \\
1.4848 \\
1.4800 \\
1.4732\end{array}$ & $\begin{array}{l}1.4062 \\
1.4581 \\
1.4556 \\
1.4537 \\
1.4510 \\
1.4486 \\
1.4446\end{array}$ & $\begin{array}{l}85.0 \\
83.0 \\
82.3 \\
79.8 \\
78.2 \\
70.0 \\
58.0\end{array}$ & $\begin{array}{r}34.4 \\
30.4 \\
26.0 \\
22.5 \\
17.0 \\
12.8 \\
5.2\end{array}$ & $\begin{array}{r}32 \\
33 \\
34 \\
34 \\
36 \\
33 \\
33 \\
\text { Average__._34 }\end{array}$ \\
\hline
\end{tabular}

a The number of theoretical plates was determined to the nearest one-half plate. 
The refractive indices shown in table 2 are the average values for two samples, one taken from the still 10 minutes after the other. The individual values of refractive index differed only by amounts ranging from 0.0000 to 0.0004 , which indicated that equilibrium had been established. There was an increase from 20 to 36.5 in the value of $(n-1)$ plates when the diameter of the balls decreased from about 4 to about $2 \mathrm{~mm}$. The locket chain and the $2-\mathrm{mm}$ lead balls gave the greatest number of theoretical plates. ${ }^{7}$

The values of the number of theoretical plates obtained for various regions of the phase diagram show the extreme deviations to be as follows: for locket chain, about 10 percent, and for balls, about 5 percent. The greatest mean deviation, however, is about 3 percent. These variations may be due to the fact that channeling differed from time to time. While the absolute magnitude of the number of theoretical plates may be in error by an appreciable amount, the authors believe that, relative to one another, the values are quite reliable. The balls would be expected to be more evenly distributed, and hence exhibit less channeling, than packings with a less symmetrical form. This may account for the smaller deviations obtained with the ball type of packing. An excellent discussion and tabulation of the values of hetp obtained with columns of different size and with various packings is given by Fenske, Tongberg, and Quiggle [6].

\section{DETERMINATION OF HOLD-UP}

The amount of material held in the rectifying column as vapor and as liquid together with the vapor in the pot is the quantity determined as the hold-up under operating conditions.

In order to determine the hold-up when operating the still at the optimum back pressure, the two-component mixture of benzene and dibutyl phthalate was employed [7]. The dibutyl phthalate was first distilled in a molecular still and the head fractions were rejected. The boiling point of the dibutyl phthalate was about $340^{\circ} \mathrm{C}$. The benzene had the constants given in section III.

A mixture of benzene and dibutyl phthalate of a known weight relationship was added to the pot of a dry still. On distillation, the vapor in the pot and the vapor and liquid in the column consisted essentially of pure benzene, because the very much higher-boiling dibutyl phthalate remained in the still pot [8]. A sample of the liquid in the pot was withdrawn while the still was operating under total reflux. The new weight relationship of benzene to dibutyl phthalate was determined by first weighing the sample, and then weighing again after distilling off the benzene. The weight of benzene associated with the total weight of dibutyl phthalate before and after distillation represents the hold-up of benzene. To prevent a loss of benzene during the removal of the sample from the hot still pot, the receiver $I$ was surrounded with a slush of solid carbon dioxide in a 50:50 solution of chloroform and carbon tetrachloride. This mixture maintains a temperature of approximately $-75^{\circ} \mathrm{C}$.

For the highest efficiency of separation obtainable with single-turn helices, see Tongberg, Lawroski, and Fenske [5]; for glass bubbling-cap columns, see Bruun and Faulconer [9]. 
The ball packings in table 4 show a change in hold-up of 56 to $74 \mathrm{ml}$ for a decrease in diameter of 4.05 to $2.05 \mathrm{~mm}$. The locket chain gave the largest hold-up.

\section{DETERMINATION OF VAPOR VELOCITY}

The vapor velocity of the packings was determined from the values of through-put ${ }^{8}$ and free space. The through-put was determined at the optimum back pressure by distilling benzene through the column with no reflux to the still. This was done by keeping the glassjacketed tube $B$ (fig. 1 ) hot and condenser $C$ cold. The rate of collection of distillate in receiver $E$ was timed with a stop watch. A correction was applied for the partial condensation at $B$.

The free space offered by the packings was obtained by measuring the amount of kerosene necessary to fill the interstices. The mean deviation between determinations was of the order of 1 to 2 percent. The free space of the ball packings was nearly constant, the deviation being 4 percent. For the packings investigated, table 3 shows the comparison of free space, vapor velocity, through-put, and the computed rate of distillation with a given reflux ratio.

TABLE 3.-Comparison of different packings

\begin{tabular}{|c|c|c|c|c|c|c|}
\hline \multirow{2}{*}{ Type of packing } & \multirow{2}{*}{$\begin{array}{l}\text { Vapor } \\
\text { velocity }\end{array}$} & \multirow{2}{*}{$\begin{array}{l}\text { Free } \\
\text { space }\end{array}$} & \multirow{2}{*}{ Through-put } & \multicolumn{2}{|c|}{$\begin{array}{c}\text { Calculated rate of distilla- } \\
\text { tion }\end{array}$} & \multirow{2}{*}{$\begin{array}{l}\text { Height } \\
\text { equiva. } \\
\text { lent to } \\
\text { one the- } \\
\text { oretical } \\
\text { plate (un- } \\
\text { der total } \\
\text { reflux) }\end{array}$} \\
\hline & & & & $\underset{9: 1}{\operatorname{Reflux}}$ ratio & $\underset{19: 1}{\text { Reflux ratio }}$ & \\
\hline $\begin{array}{l}\text { Glass balls }(3.80 \mathrm{~mm} \text { diam }) \\
\text { Copper balls }(4.00 \mathrm{~mm} \text { diam }) \\
\text { Glass balls plus copper balls }(50: \\
50 \text { mixture; glass, } 3.8 \mathrm{~mm} \text { diam; } \\
\text { copper, } 4.0 \mathrm{~mm} \text { diam })\end{array}$ & $\begin{array}{r}\mathrm{m} / \mathrm{min} \\
32.0 \\
28.0\end{array}$ & $\begin{array}{r}\mathrm{cm}^{3} \\
238 \\
244\end{array}$ & $\begin{array}{c}\mathrm{ml}(\mathrm{liq}) / \mathrm{min} \\
20 \\
18 \\
\\
21\end{array}$ & $\begin{array}{r}\mathrm{ml}(\mathrm{liq}) / \mathrm{min} \\
2.0 \\
1.8\end{array}$ & $\begin{array}{r}\mathrm{ml}(\mathrm{liq}) / \min \\
1.0 \\
0.9\end{array}$ & $\begin{array}{l}\mathrm{cm}_{5.58} \\
5.86 \\
\\
6.0\end{array}$ \\
\hline $\begin{array}{l}\text { Glass balls }(2.95 \mathrm{~mm} \text { diam }) \\
\text { Lead balls }(2.05 \mathrm{~mm} \text { diam }) \\
\text { Locket chain }\end{array}$ & $\begin{array}{l}25.7 \\
24.5 \\
20.3\end{array}$ & $\begin{array}{l}233 \\
238 \\
413\end{array}$ & $\begin{array}{l}15.5 \\
15 \\
21.5\end{array}$ & $\begin{array}{l}1.5 \\
1.5 \\
2.1\end{array}$ & $\begin{array}{r}.7 \\
.7 \\
1.0\end{array}$ & $\begin{array}{l}\text { 4. } 28 \\
\text { 3. } 28 \\
\text { 3. } 5_{6}\end{array}$ \\
\hline
\end{tabular}

The results shown in table 3 indicate that it is possible to obtain higher vapor velocities with the ball type of packing than with the locket chain. However, the smaller free space in ball packing reduces the amount of through-put that can be realized. The results indicate that locket chain is superior from the standpoint of ample free space, whereas balls are better from the standpoint of vapor velocity. These two factors govern the through-put of a column. It appears, however, that the speed with which vapor can travel through packing, without loss in efficiency of rectification, is governed by the way in which the free space is distributed. The ideal type of packing appears to be one that combines the uniform distribution of free space offered by ball packings and the greater amount of free space in relation to surface offered by chain packings. Equal distribution would permit higher vapor velocities without loss in efficiency of separation by partial flooding, channeling, entrainment, or passage of vapor without rectification. Furthermore, it is desirable to have

\footnotetext{
- The amount of distillate collected in a given time.
} 
the maximum surface for separation that is compatible with the free space necessary for the desired through-put.

\section{DETERMINATION OF THE SURFACE AREA OF PACKING}

The surface area of the packings was calculated from the following: the total weight of units as packing in the tube, the weight of an individual unit, and the volume of the total number of units. The surface area of the ball packings was computed from their radii, considering the units to be spheres. The values of the radii, computed from the volume of an individual unit, differed from those obtained by direct measurement by about 2 percent. In the case of the chain packing the surface area was calculated by assuming each unit to have the shape of a cylindrical rod. Their radii were determined by direct measurement and their length was computed from their volume. The calculated length of each unit was checked by measuring its circumference and the two values were found to agree within 7 percent. The estimated total error in the area calculated for the chain packing was about 10 percent. The values in table 4 show the calculated surface areas of the amounts of different packings required to fill a tube $2.58 \mathrm{~cm}$ in diameter and $120 \mathrm{~cm}$ long. The effective surface area of the packing is less than the calculated area by the amount lost by contact of the units in packing. Of the total calculated area, that percentage which is effective for separation would be expected to be smallest for the locket chain packing and greatest for the ball packings.

\section{TABLE 4.-Summary of data obtained on the various packings}

[Column used had an inside diam of $25.8 \mathrm{~mm}$; packing occupied $120 \mathrm{~cm}$ of length in each case except for the copper balls.] *

\begin{tabular}{|c|c|c|c|c|c|c|c|c|c|}
\hline Type of packing & $\begin{array}{c}\text { Diam- } \\
\text { eter }\end{array}$ & $\begin{array}{l}\text { Back } \\
\text { pres- } \\
\text { sure } \\
\text { (opti- } \\
\text { mum) }\end{array}$ & $\begin{array}{l}\text { Col- } \\
\text { umn } \\
\text { hold- } \\
\text { up } \\
\text { (oper- } \\
\text { ating } \\
\text { condi- } \\
\text { tions) }\end{array}$ & $\begin{array}{l}\text { Free } \\
\text { space }\end{array}$ & $\begin{array}{l}\text { Vapor } \\
\text { veloc- } \\
\text { ity }\end{array}$ & $\begin{array}{c}\text { Num- } \\
\text { ber of } \\
\text { theo- } \\
\text { retical } \\
\text { plates, } \\
\text { less } \\
\text { one } \\
n-1\end{array}$ & \begin{tabular}{|} 
Height \\
equiv- \\
alent \\
to one \\
theo- \\
retical \\
plate
\end{tabular} & $\begin{array}{l}\text { Calcu- } \\
\text { lated } \\
\text { surface } \\
\text { area of } \\
\text { pack- } \\
\text { ing - }\end{array}$ & $\begin{array}{l}\text { Area } \\
\text { per } \\
\text { theo- } \\
\text { retical } \\
\text { plate }\end{array}$ \\
\hline Lead balls. & $\operatorname{mm}_{\mathrm{b}(4.05)}$ & $\mathrm{mm} \mathrm{Hg}_{10}^{\mathrm{mg}}$ & $\mathrm{ml}$ & $\begin{array}{c}\mathrm{cm}^{2} \\
242\end{array}$ & $\mathrm{~m} / \mathrm{min}$ & 20 & $\begin{array}{c}\mathrm{cm} \\
6.00\end{array}$ & $\begin{array}{l}\mathrm{cm}^{2} \\
5,660\end{array}$ & $\mathrm{~cm}^{2}$ \\
\hline Copper balls & $\left\{\begin{array}{r}4.05 \\
(4.00) \\
3.98\end{array}\right.$ & 10 & - 56 & 244 & 28.0 & a $201 / 2$ & 5.88 & 5,730 & 280 \\
\hline Glass balls....... & $\left\{\begin{array}{r}(3.76) \\
3.79\end{array}\right.$ & 10 & 59 & 238 & 32.0 & $21 \frac{1}{2}$ & 5. $5_{8}$ & 6,330 & 295 \\
\hline $\begin{array}{l}\text { Glass balls plus copper } \\
\text { balls: } \\
\text { Glass balls } \\
\text { Copper balls }\end{array}$ & $\begin{array}{l}\text { 3. } 79 \\
\text { 3. } 96\end{array}$ & 10 & & & & 20 & $6.0_{0}$ & & \\
\hline Glass balls... & $\left\{\begin{array}{r}(2.97) \\
2.92\end{array}\right.$ & 12 & 64 & 233 & 25.7 & 28 & 4. 28 & 7,890 & 282 \\
\hline Lead balls. & $\left\{\begin{array}{r}(2.03) \\
2.08\end{array}\right.$ & 15 & 74 & 238 & 24.5 & $361 / 2$ & 3. $2 g$ & 11,400 & 312 \\
\hline $\begin{array}{l}\text { Locket chain (diam of rod } \\
0.33 \mathrm{~mm} \text {; circumference } \\
\text { of link } 6.2 \mathrm{~mm} \text { ) }\end{array}$ & & 10 & 81 & 413 & 20. 3 & 34 & 3. $5_{6}$ & $(24,200)$ & (712) \\
\hline
\end{tabular}

a In the case of the copper balls, the length of packing was $115 \mathrm{~cm}$. Where appropriate, the observed values of hold-up and theoretical plates have been multiplied by the factor 120/115 to obtain the value for the standard length of $120 \mathrm{~cm}$.

b The values in parentheses were obtained by direct measurement; the others were calculated as described in the text on p. 600 .

- The total surface ares exposed in the packed column is obtained by adding $1,130 \mathrm{~cm}^{2}$, the area of the walls of the column, to the surface area of the packing. 


\section{DISCUSSION OF RESULTS}

With respect to packing composed of uniformly sized spherical balls 0.2 to $0.4 \mathrm{~cm}$ in diameter in a column $2.6 \mathrm{~cm}$ in diameter, the following conclusions are made on the basis of the data obtained in the present investigation:

1. The efficiency of separation, the vapor velocity, and the hold-up are substantially independent of the heat conductivity of the packing. Table 4 shows the values obtained with lead, copper, and glass balls approximately $4 \mathrm{~mm}$ in diameter.

2. The efficiency of separation is substantially directly proportional to the total surface area exposed in the packed column. This rela-

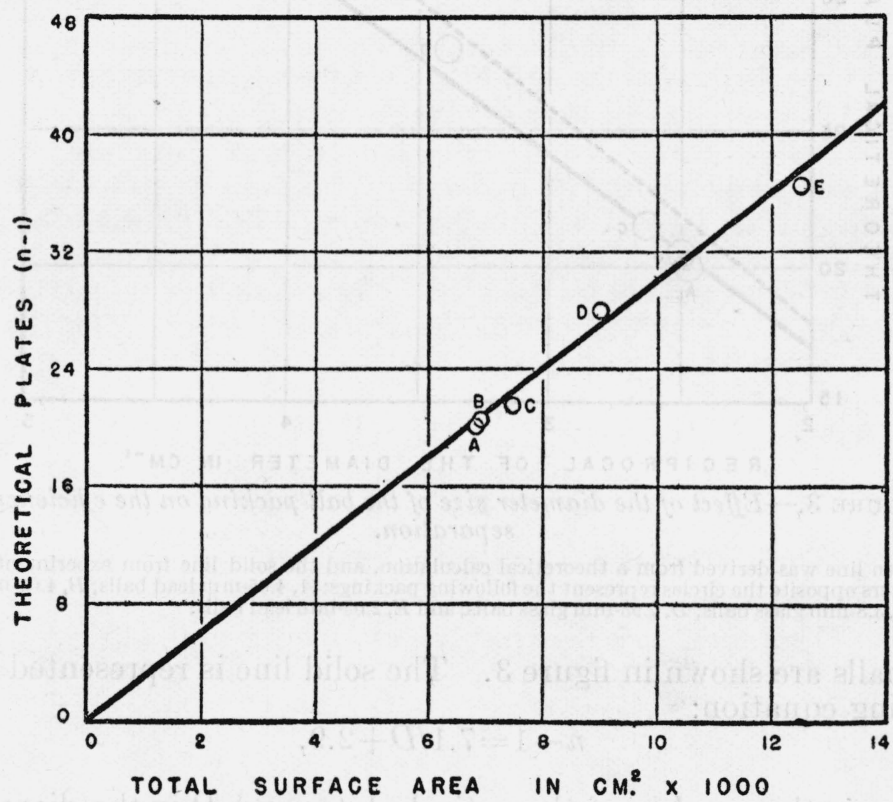

FIGURE 2.-Effect of the surface area of the ball packing on the efficiency of separation.

The letters opposite the circles represent the following packings: $A, 4.05$-mm lead balls; $B, 4.00$-mm copper balls; $C, 3.8-\mathrm{mm}$ glass balls; $D, 2.95-\mathrm{mm}$ glass balls; and $E, 2.05-\mathrm{mm}$ lead balls.

tionship for the given column and given sized balls shown in figure 2, is represented by the equation

$$
n-1=0.0030(S+s),
$$

where $n$ is the number of theoretical plates and $(S+s)$ is the total surface area exposed in the packed column in square centimeters, $S$ being the total surface area of the balls and $s$ being the internal surface area of the column.

3. The hold-up is approximately linear with the total surface area of the balls, the relation being

$$
H=0.0032 S+38,
$$

where $H$ is the hold-up in milliliters.

Since, in a large container filled with small balls of a uniform diameter, the volume of the void space and the volume occupied by 
the material of the balls are each substantially constant and independent of the diameter of the balls, it follows that the surface area of the balls is substantially inversely proportional to the diameter ${ }^{9}$ of the balls. The experimental data for the given column and given

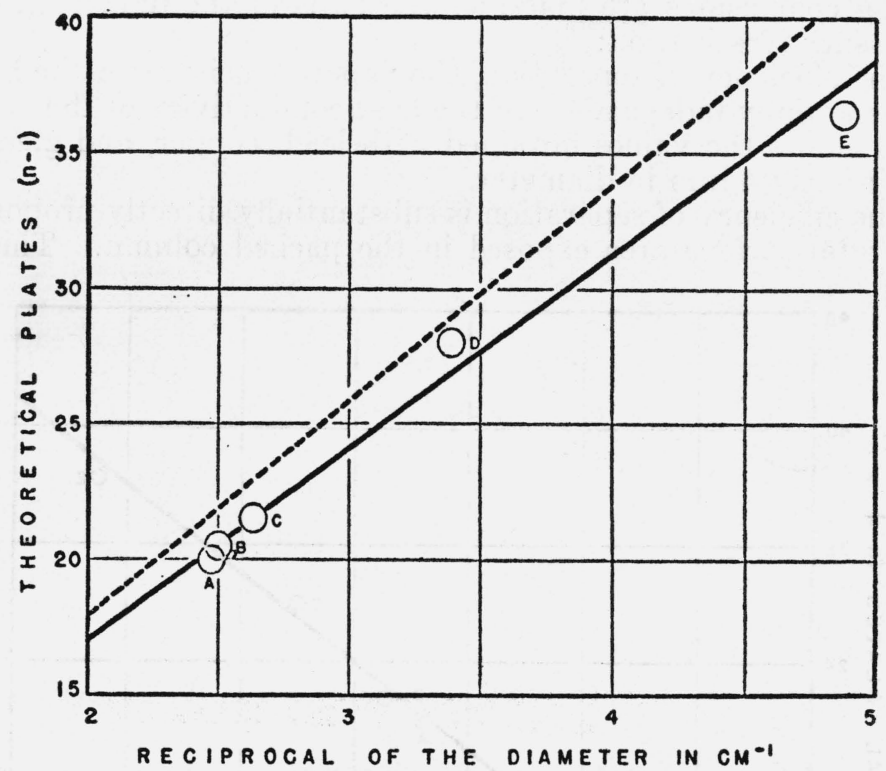

Figure 3.-Effect of the diameter size of the ball packing on the efficiency of separation.

The broken line was derived from a theoretical calculation, and the solid line from experimental values. The letters opposite the circles represent the following packings: $A, 4.05-\mathrm{mm}$ lead balls; $B, 4.00-\mathrm{mm}$ copper balls; $C, 3.8$-mm glass balls; $D, 2.95$-mm glass balls; and $E, 2.05$-mm lead balls.

sized balls are shown in figure 3 . The solid line is represented byithe following equation:

$$
n-1=7.1 / D+2.9 \text {, }
$$

where $n$ is the number of theoretical plates and $D$ is the diameter of the balls in centimeters.

For a container in which the size of the balls is not infinitesimal in comparison with the dimensions of the container, a simple approximate calculation can be made of the relation between the total volume of the container, the free or void space, the volume actually occupied by the material of the balls, and the total surface area of the balls. Assuming, for simplicity, a rectangular parallelopiped of cross section and length equivalent to that of the column actually used in the present investigation, and taking cognizance of the extra free space occurring near the walls of the container, with the balls in the center being packed ideally so that each ball touches twelve others, the following relationships may be obtained:

$$
N=V /\left(0.707 D^{3}\right)-292 / D^{2}
$$

- For an individual ball the surface area is proportional to the diameter squared, and the total number of balls is inversely proportional to the diameter cubed. The net result is that the surface area of the ball packing is inversely proportional to the diameter. 


$$
\begin{aligned}
& F=0.259 V+153 D \\
& S=4.45 V / D-918
\end{aligned}
$$

where $N$ is the total number of balls, $V$ is the volume of the container in cubic centimeters, $D$ is the diameter of each ball in centimeters, $F$ is the free or void space in cubic centimeters, and $S$ is the total surface area of the balls.

The substitution of the value of $S$ from eq 6 above and the value of $s$, the area of the inner walls of the rectifying tube $\left(1130 \mathrm{~cm}^{2}\right)$, into the previously determined eq 1 yields the following equation for the number of theoretical plates in relation to the diameter of the balls in the given column, the equation being represented in figure 3 by the broken line:

$$
n-1=8.3 / D+1.6 \text {, }
$$

where $n$ is the number of theoretical plates and $D$ is the diameter in centimeters. For balls ranging in diameter from 0.2 to $0.4 \mathrm{~cm}$, the "theoretically" derived eq 7 is in substantial accord with the analogous eq 3 derived from experimental data.

Other types of packings may show a similar relationship between the surface area of the packing with the number of theoretical plates. It may be concluded that the ideal packing is the one that gives a uniform distribution of free space in the column, with the maximum surface for separation compatible with the free space necessary for the desired through-put.

The authors express their gratitude to Prof. M. M. Haring of the Department of Chemistry at the University of Maryland, for his kind interest, aid, and criticism during the present investigation, and to F. D. Rossini, Director of the American Petroleum Institute Research Project 6 , for his guidance in the work and for his suggestions in connection with the analyses and presentation of the data. The authors also acknowledge the helpful advice of J. D. White and F. W. Rose, Jr., and the experimental assistance of P. E. Schoonover, C. L. Miller, and F. W. Melpolder.

\section{REFERENCES}

[1] J. H. Bruun and S. T. Schicktanz, BS J. Research 1, 851 (1931) RP379.

[2] E. Pahlavauni, Bul. soc. chim. Belg. 36, 533 (1927).

[3] W. L. McCabe and E. W. Thiele, Ind. Eng. Chem. 17, 605 (1925).

[4] Arthur Rose, Ind. Eng. Chem. 28, 1210 (1936).

[5] C. O. Tongberg, S. Lawroski, and M. R. Fenske. Ind. Eng. Chem. 29, 957 (1937).

[6] M. R. Fenske, C. O. Tongberg, and D. Quiggle. Ind. Eng. Chem. 26, 1169 (1934).

[7] C. O. Tongberg, D. Quiggle, and M. R. Fenske. Ind. Eng. Chem. 26, 1213 (1934).

[8] E. W. Washburn and J. W. Read. J. Am. Chem. Soc. 41, 729 (1919).

[9] J. H. Bruun and W. B. M. Faulconer. Ind. Eng. Chem., Anal. Ed. 9, 192 (1937).

Washington, September 11, 1937. 